\title{
Mead Johnson Award-1987
}

Follow this and additional works at: https://jdc.jefferson.edu/jeffjpsychiatry

Part of the Psychiatry Commons

Let us know how access to this document benefits you

\section{Recommended Citation}

(1987) "Mead Johnson Award-1987," Jefferson Journal of Psychiatry. Vol. 5 : Iss. 2 , Article 3.

DOI: https://doi.org/10.29046/JJP.005.2.011

Available at: https://jdc.jefferson.edu/jeffjpsychiatry/vol5/iss2/3

This Article is brought to you for free and open access by the Jefferson Digital Commons. The Jefferson Digital Commons is a service of Thomas Jefferson University's Center for Teaching and Learning (CTL). The Commons is a showcase for Jefferson books and journals, peer-reviewed scholarly publications, unique historical collections from the University archives, and teaching tools. The Jefferson Digital Commons allows researchers and interested readers anywhere in the world to learn about and keep up to date with Jefferson scholarship. This article has been accepted for inclusion in Jefferson Journal of Psychiatry by an authorized administrator of the Jefferson Digital Commons. For more information, please contact: JeffersonDigitalCommons@jefferson.edu. 


\section{Mead Johnson Award 1987}

The editorial board of The Jefferson Journal of Psychiatry-A Resident Publication is pleased to announce the winner of the first annual Mead Johnson Award for excellence in writing as submitted to the Journal. Paul V. Trad, M.D. has received the one thousand dollar award for his work, "Infant Depression: Nature Seeking Nurture" ( $J J P 5(1)$ 15-33, 1987). His ambitious synthesis exemplifies the creative potential within residency and fellowship programs. We hope that this further acknowledgement of Dr. Trad's work will help to inspire other trainees to undertake such an effort.

The Mead Johnson Award has been established to honor the best paper submitted to the Journal during each calendar year, as judged by the editorial board. An award of one thousand dollars is given to the chosen author, with an additional one thousand dollars to be given to the residency program or fellowship in which the author is enrolled. Manuscripts on any topic are welcome from psychiatric trainees, as detailed in the Information for Contributors section. 